\title{
Development of a lumbosacral intervertebral cage prototype for $\operatorname{dogs}^{1}$
}

\author{
Raíra C. Dias ${ }^{2}$, Ana Carolina Tsatsakis ${ }^{3}$ and Mônica V. Bahr Arias²* (D)
}

\begin{abstract}
Dias R.C., Tsatsakis A.C. \& Bahr Arias M.V. 2020. Development of a lumbosacral intervertebral cage prototype for dogs. Pesquisa Veterinária Brasileira 40(7):546-553. Departamento de Clínicas Veterinárias, Universidade Estadual de Londrina, Rodovia Celso Garcia Cid Km 380, Londrina, PR 86057-970, Brazil. E-mail: vicky@uel.br

Several surgical procedures aim to decompress and/or stabilize the lumbosacral (LS) joint of dogs; however, the lumbar interbody fusion technique, by using a cage combined with a bone graft, is the most indicated and used in human medicine. No specific implant is available for application to the canine lumbosacral joint. Thus, this study measured lumbosacral discs in large dogs, determined whether a human cage model could fit the dogs' L7-S1 intervertebral space, and developed a LS cage prototype for dogs. Ten cadaveric lumbosacral spines from adult dog weighing 20-35kg were used. The dogs had died for reasons unrelated to this study. The vertebral body dimensions and the L7-S1 intervertebral space occupied by the intervertebral disc were measured by lateral and ventrodorsal radiographs and by computed tomography in the dorsal, sagittal, and transverse views. Measurements were also taken of the anatomical specimens in the sagittal and transverse planes. After measuring the intervertebral discs, the following mean measures were obtained for L7-S1 discs: height $12.23 \mathrm{~mm}$, dorsal thickness $3.3 \mathrm{~mm}$, central thickness $4 \mathrm{~mm}$, ventral thickness $5.5 \mathrm{~mm}$, and width $24.74 \mathrm{~mm}$. The human lumbar cage models from brands LDR, Baumer Orthopedics, Stryker, Synthes, and Vertebral Technologies, Inc. and cervical stabilization cages from the brands B-Braun and Stryker were evaluated and were found to be unsuitable for large dogs. Cervical human cages had measurements similar to those found in this study; however, due to their quadrangular shape, the possibility of being introduced surgically through the surgical accesses available for the articulation between L7-S1 in dogs without injuring the cauda equina or the L7 root is small. A cage model was then developed using 3D modelling software. It was designed for insertion via dorsal laminectomy in the lateral portions of the intervertebral space. To avoid cauda equina lesion, the implant model was developed to be placed laterally to the midline. The cage surface is serrated to prevent using the locking screw to fix it, thus avoiding further injury to nerve structures. The serrated surfaces are also designed to avoid cage migration and promote stability. The prototype allows graft placement in the surrounding intervertebral space, which is fundamental for fusion through integration between the cage and the endplates as well as for bone growth between and around the cage. It was also considered studies on humans showing that the lateral regions of the endplates support a more considerable load. Biomechanical and in vivo studies on the developed model are necessary to evaluate the actual degree of distraction, mobility and the long-term rate of fusion between L7 and S1 and its possible impact on the adjacent motor units, combined or not with dorsal fixation techniques.
\end{abstract}

INDEX TERMS: Lumbosacral, intervertebral cage, prototype, degenerative diseases, surgery, dogs.

\footnotetext{
${ }^{1}$ Received on September 12, 2019.

Accepted for publication on May 5, 2020.

Part of Master's Thesis of the first author.

${ }^{2}$ Departamento de Clínicas Veterinárias, Universidade Estadual de Londrina (UEL), Rodovia Celso Garcia Cid PR-445 Km 380, Londrina, PR 86051-990, Brazil. *Corresponding author: vicky@uel.br

${ }^{3}$ Curso de Design, Universidade Federal de Uberlândia (UFU), Av. João Naves de Ávila 2121, Santa Mônica, Uberlândia, MG 38408-100, Brazil.
}

RESUMO.- [Desenvolvimento de um protótipo de cage intervertebral lombossacro para cães.] Vários procedimentos cirúrgicos visam descomprimir e/ou estabilizar a articulação lombossacra (LS) de cães; no entanto, a técnica de fusão lombar, usando um cage intersomático combinado com um enxerto ósseo, é a mais indicada e utilizada na medicina humana. Não há implante específico disponível para aplicação 
na articulação lombossacra canina. Assim, neste estudo foi realizada a mensuração do espaço do disco intervertebral lombossacro de cães de raças grandes, para verificar se algum modelo de cage usado na medicina humana poderia ser usado no espaço intervertebral L7-S1 de cães. 0 segundo objetivo foi desenvolver um protótipo de cage lombossacro para cães. Foram utilizadas dez colunas lombossacras provenientes de cadáveres de cães adultos com peso entre 20 e $35 \mathrm{~kg}$. Os cães vieram a óbito por razões não relacionadas a este estudo. As dimensões do corpo vertebral e o espaço intervertebral L7-S1 ocupado pelo disco intervertebral foram medidos por radiografias laterais e ventrodorsais e por tomografia computadorizada nos cortes dorsal, sagital e transversal. Também foram realizadas mensurações das peças anatômicas nos planos sagital e transversal. Após a mensuração dos discos intervertebrais, foram obtidas as seguintes medidas médias dos discos L7-S1: altura 12,23mm, espessura dorsal 3,3mm, espessura central $4 \mathrm{~mm}$, espessura ventral $5,5 \mathrm{~mm}$ e largura $24,74 \mathrm{~mm}$. Os modelos de cage lombar humano das marcas LDR, Baumer Orthopaedics, Stryker, Synthes e Vertebral Technologies, Inc. não possuíam dimensões adequadas para os cães. Cages de estabilização cervical das marcas B-Braun e Stryker também foram avaliados e apresentaram medidas semelhantes às encontradas neste estudo; no entanto, devido à sua forma quadrangular, a possibilidade de serem introduzidos cirurgicamente através das abordagens disponíveis para a articulação entre L7-S1 em cães sem lesionar a cauda equina ou a raiz L7 é pequena. Um modelo de cage foi então desenvolvido usando-se o software de modelagem 3D. Foi projetado para inserção via laminectomia dorsal nas porções laterais do espaço intervertebral. Para evitar a lesão da cauda equina, o modelo de implante foi desenvolvido para ser colocado lateralmente à linha média. A superfície do cage é serrilhada para evitar o uso do parafuso de travamento, evitando-se lesões adicionais às estruturas nervosas. As superfícies serrilhadas também foram projetadas para evitar a migração do cage e promover estabilidade. 0 protótipo permite a colocação do enxerto no espaço intervertebral circundante, fundamental para a fusão através da integração entre o cage e as placas vertebrais terminais, bem como para o crescimento ósseo entre e ao redor do implante. Também foram considerados estudos em seres humanos que mostraram que as regiões laterais das placas vertebrais terminais suportam uma carga maior. São necessários estudos biomecânicos e in vivo do modelo desenvolvido para avaliar o grau real de distração, mobilidade e a taxa de fusão a longo prazo entre L7 e S1 e seu possível impacto nas unidades motoras adjacentes, quando combinado ou não com técnicas de fixação dorsal.

TERMOS DE INDEXAÇÃO: Lombossacro, dispositivo intersomático intervertebral, protótipo, doenças degenerativas, cirurgia, cão, caninos.

\section{INTRODUCTION}

The canine lumbosacral junction (L7-S1) is a joint with great mobility that can be affected by several conditions. Among these, degenerative lumbosacral stenosis (DLS) is the most common cause of canine lumbosacral disease. A combination of anatomical and biomechanical changes in the joint can cause compression of the cauda equina and nerve roots (Meij \& Bergknut 2010, Jeffery et al. 2013). DLS shares some similarities with lumbar degenerative spine disease (LDSD), as they both affect the cauda equina and can cause lameness, lower back pain, and neurological deficits (Jeffery et al. 2014, Bebchuck 2017). Studies on LDSD may contribute to better understanding DLS, and dogs can be used as natural models for studying the disease in humans (Meij \& Bergknut 2010).

The main surgical techniques described for dogs with DLS are dorsal decompressive laminectomy, combined or not with disc fenestration, lateral foraminotomy, dorsal fixation, and in some cases facetectomy, which promotes decompression of the L7 nerve root (Gomes et al. 2018). However, there are variable results with these surgical techniques, as they do not eliminate all causes of compression and do not promote fusion (Jeffery et al. 2014, Bebchuck 2017).

Surgical procedures to promote lumbar interbody fusion are well-established treatments in human medicine. Among the several described techniques, posterior lumbar fusion using cages or lumbar spacers combined with autologous cancellous bone graft placement is a surgery with the best biomechanical results (Kim et al. 2012). These cages were developed to restore standard disc height, distract the neuroforamina and increase biomechanical rigidity, thus reducing the pedicle fixation technique failures observed in the spinal stabilization technique in humans (Polly et al. 2000, Cho et al. 2008).

In veterinary medicine, few studies exist about cage implantation between the L7 and S1 vertebrae. Recently, the Fitz intervertebral traction screw (FITS), a conical and threaded titanium spacer screw, was developed for use in several intervertebral spaces (Solano et al. 2015). In dogs with DLS, combining this screw with a stabilization technique using pins and bone cement allowed indirect decompression of the L7 foramen and long-term vertebral stability (Farrel \& Fitzpatrick 2015). In cadaveric canine lumbosacral spines, a polyaxial screw-clamp fixation system was used in combination with an intervertebral distraction bolt demonstrating that the new implant system restores stability to the lumbosacral junction following destabilization (Zindl et al. 2018). In an ex vivo study, a cage used in human medicine to promote cervical intervertebral fusion was inserted into the lumbosacral joint of nine canine lumbosacral segments (Teunissen et al. 2017). The biomechanical properties were assessed with the cage alone and combined with pedicle screw-rod fixation (PSRF), resulting in increased disc height, reduced range of motion, and improved joint stabilization. The authors concluded that cage insertion is an alternative to dorsal fixation; however, the cage was more easily inserted into the vertebral segments of larger dogs, emphasizing the need to develop a specific intervertebral device for dogs (Teunissen et al. 2017).

Due to the limited studies evaluating intervertebral spacers for dogs, this study performed an anatomical, radiographic and tomographic evaluation of the lumbosacral joint in large dogs, with and without radiographic or tomographic signs of DLS, to determine whether a human cage model had adequate dimensions for this joint and to develop a cage prototype for dogs.

\section{MATERIALS AND METHODS}

Ethics statement. All procedures were approved by the Institutional Ethics Committee on Animal Use, under protocol number 9360.2016.64. 
Phase one. Ten lumbosacral vertebral segments were collected from adult dog cadavers with and without radiographic and tomographic signs of DLS, with weights ranging from 20 to $35 \mathrm{~kg}$ (median 27.95) and having died due to conditions unrelated to this study. Spines were collected between the L7 and the sacrum with the surrounding musculature and pelvis to maintain the lumbosacral and sacroiliac joints intact. Each specimen was wrapped in compresses moistened with saline, placed in a plastic bag, stored at $-20^{\circ} \mathrm{C}$, and then kept in a refrigerator at $4^{\circ} \mathrm{C}$ for 24 hours to perform the procedures described below. The spines were radiographed in the laterolateral (LL) and ventrodorsal (VD) projections to exclude any specimens with anatomical abnormalities, including fractures, neoplasms, or other congenital malformations. Specimens with degenerative changes compatible with DLS were used in the study. The spines were then subjected to helical computed tomography (CT), with $150 \mathrm{Ma}$ and $120 \mathrm{kV}$, in $3 \mathrm{~mm}$ slices in the bone window, using a GE HiSpeed Fxi CT scanner.

The specimens were divided into two groups to measure the vertebral bodies dimensions and intervertebral disc (IVD). Group I was represented by five lumbosacral spines sectioned in the sagittal plane to measure the height of the space occupied by the intervertebral disc and the L7-S1 disc thickness at three levels. Group II was represented by the other spines, which were sectioned on the transverse axis at the level of the intervertebral space, to evaluate the width and height of the L7-S1 disc. The sections were made with a medical electrical saw drill (BJJ-l/Bojin $\left.{ }^{\circledR}\right)$ with a blade $90 \mathrm{~mm}$ long and $0.8 \mathrm{~mm}$ thick. All specimen measurements were made with a calliper.

To compare whether the radiographic and tomographic measurements were similar to those measured directly on the anatomical specimens, four measurements were made in a sagittal section, as follows: T1, thickness of the dorsal portion of the intervertebral disc; T2, thickness of the central portion of the disc; $\mathrm{T} 3$, thickness of the ventral portion of the disc; and DH, the disc height at its centre. These measurements were then compared with those from the radiographs and CT scans (Fig.1).

In all transverse specimens, the greatest intervertebral disc width was measured at its central point (W), and the heights of the vertebral endplates of the $\mathrm{L} 7$ vertebral body were measured at the central point (H2) and laterally ( $\mathrm{H} 1$ and $\mathrm{H} 3$ ). The same measurements were performed on the CT scans (Fig.2). The intervertebral space between L7 and S1 on all CT scans was measured at three levels
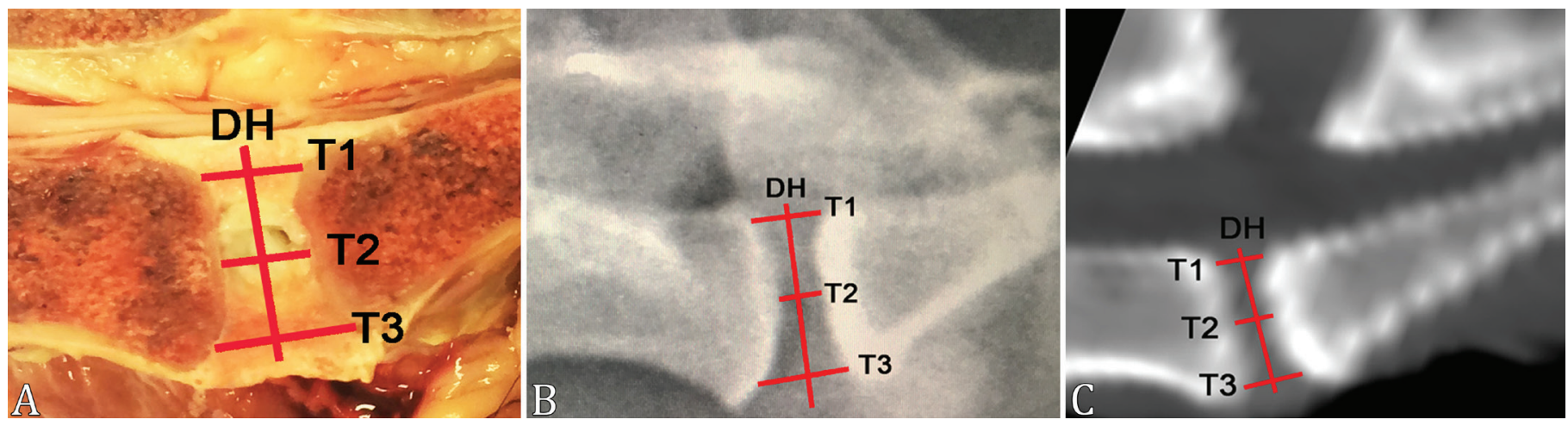

Fig.1. L7-S1 intervertebral disc measurements of the canine lumbosacral vertebrae in the sagittal section (Group I). (A) Anatomical specimen, (B) radiography, (C) computed tomography. Disc dorsal thickness (T1), disc medial thickness (T2), disc ventral thickness (T3), disc height (DH).
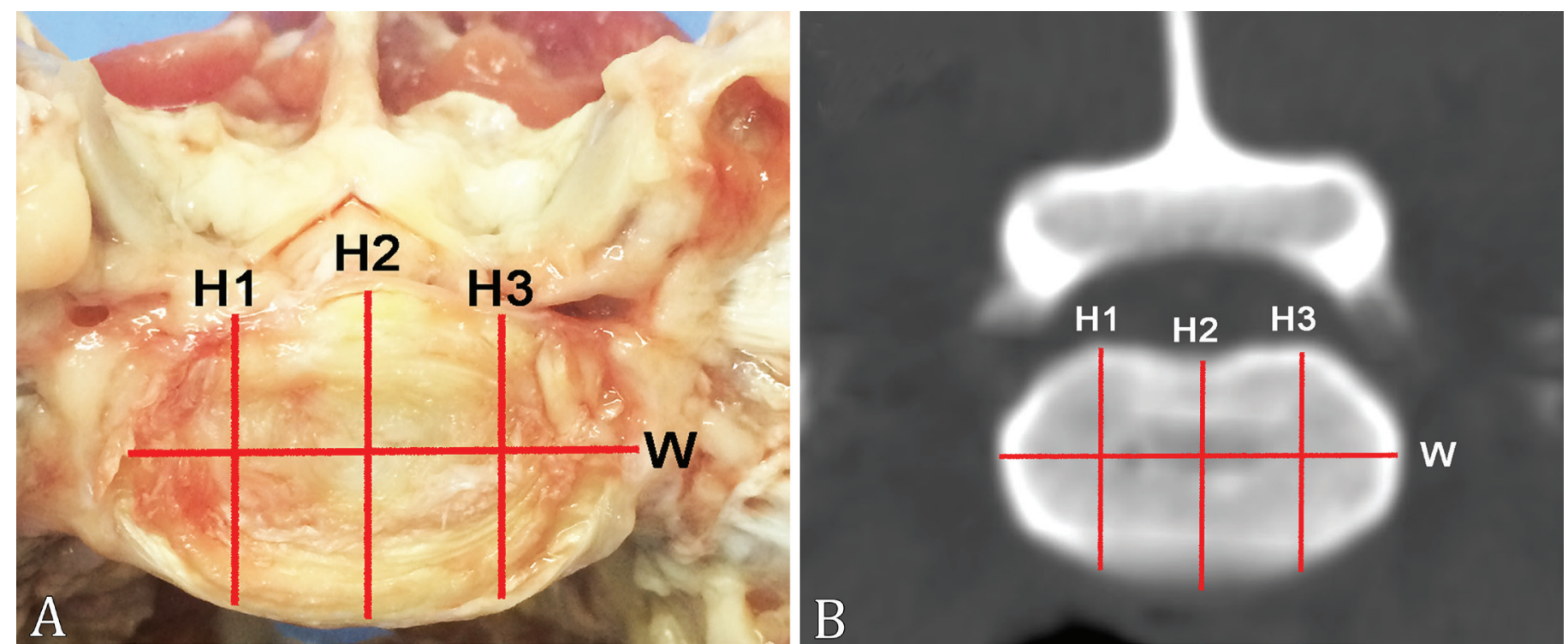

Fig.2. L7-S1 intervertebral disc measurements of the canine lumbosacral vertebrae in the transverse section. (A) Anatomical specimen,

(B) Tomography. Height lateral measurements (H1 and H3), height central measurement (H1 and H3), width (W). 
and two lateral points to define the prosthesis thickness: V1, the lateral thickness of the intervertebral space in its dorsal portion; V2, the lateral thickness of the intervertebral space in its central portion; and V3, the lateral thickness of the intervertebral space in its ventral portion (Fig.3). Disc thickness was also measured at two lateral points in the ventrodorsal plane by radiography and CT scan.

Phase two. After obtaining the disc thickness, height and width, the dimensions from cages used in humans for intervertebral fusion were evaluated to verify compatibility with the measurements obtained for the specimens. Cages used in the lumbosacral region were evaluated for the brands LDR, Baumer Orthopedics, Stryker, Synthes, and Vertebral Technologies, Inc. In addition, cervical stabilization cages from the brands B-Braun and Stryker were also evaluated.

Phase three: prosthesis development. A prosthesis model was developed using 3D MAX 2015, modelling software used for product design, based on width, thickness, height and the analysed geometries.

Statistical analysis. Measurements of the anatomical specimens' sagittal sections were compared with their respective radiographs and CT scans for the ten specimens, independently of the section plan group. Next, the measurements obtained from the anatomical specimens, CT scans and radiographs were compared within groups I (sagittal section) and II (transversal section). The data were analysed for normality using the arithmetic mean and simple standard deviation. The parametric t-test was used to compare measurements between the two groups. Finally, the parametric Tukey test was used for comparing three groups, and the nonparametric Mann-Whitney test was used for analysis between two groups.

\section{RESULTS}

Phase one. Breed, age, weight, and sex data on the dogs used in the study are presented in Table 1. Mean cadaver weight was $27.05 \mathrm{~kg}$ and mean age was 6.9 years, with the same proportion of males and females. The following mean measures were obtained for L7-S1 discs: height $12.23 \mathrm{~mm}$, dorsal thickness $3.3 \mathrm{~mm}$, central thickness $4 \mathrm{~mm}$, ventral thickness $5.5 \mathrm{~mm}$, and width $24.74 \mathrm{~mm}$ (Table 2 and 3). Radiographic and tomographic signs of degeneration were found in the lumbosacral joints of four dogs (Table 1), two males and two females. These changes included spondylosis deformans, vertebral end plate sclerosis and intervertebral foramen stenosis. None of these dogs presented clinical signs of DLS or any other condition associated with the spine or spinal cord in segments other than L7-S1 in the ante mortem period, according to the history reported by the owners and previously performed clinical examination.

The mean measurements of the L7-S1 disc are shown in Tables 2 and 3. In comparing the measurements of the anatomical specimens in sagittal section with the radiographs (radiography $\mathrm{x}$ specimen) and the CT scans (CT scan $\mathrm{x}$ specimen), no significant differences were observed ( $p>0.05)$ for the T1, T2 and T3 measurements. Further, no significant difference $(p>0.05)$ was found for the height of the disc (DH) $(p=0.906)$, nor were any significant differences found $(p>0.05)$ in comparing the $\mathrm{H} 1, \mathrm{H} 2, \mathrm{H} 3$ measurements and $\mathrm{W}$ transverse sections (measured only in the anatomical specimens and on the CT scans due to the impossibility of obtaining transverse radiographs). The thickness measurements obtained by radiographs (V1) in the ventrodorsal plane and the CT scans
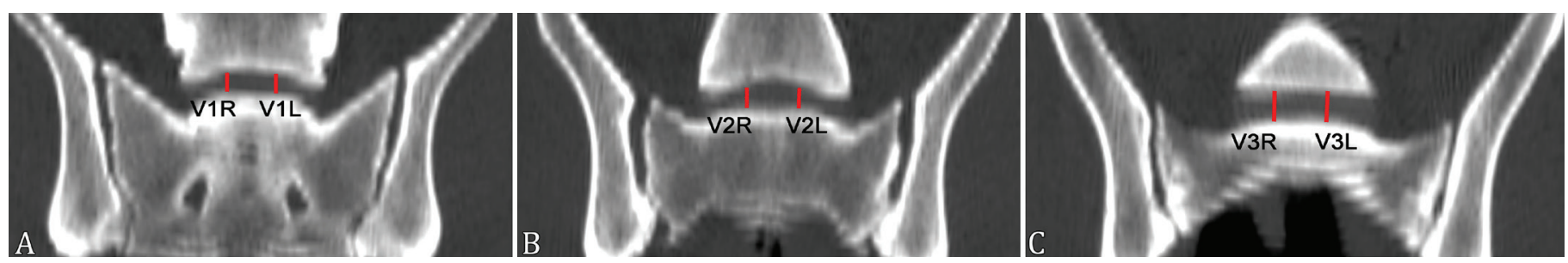

Fig.3. L7-S1 intervertebral disc measurements of canine lumbosacral specimens performed on computed tomography in the dorsal view. (A)

Thickness of the lateral portion of the intervertebral space in the dorsal portion, (B) thickness of the lateral portion of the intervertebral space in the medial portion, (C) thickness of the lateral portion of the intervertebral space in the ventral portion.

Table 1. Epidemiological aspects of dogs used in the study, including breed, weight, sex, age, and presence or absence of degenerative signs between L7 and S1. Group I represented by spines sectioned in the sagittal plane and Group II represented by spines sectioned on the transverse axis

\begin{tabular}{cccccc}
\hline Group & Breed & Weight $(\mathrm{kg})$ & Sex & Age (years) & $\begin{array}{c}\text { Presence of degenerative } \\
\text { signs between L7 and S1 }\end{array}$ \\
\hline G I & Undefined & 20 & Male & Adult & Yes \\
G II & Akita & 25 & Female & Adult & No \\
G I & Rottweiler & 31.8 & Female & 9 & No \\
G II & German Shepherd & 28 & Male & 7 & Yes \\
G I & Labrador Retriever & 26.3 & Female & No & Yes \\
G I & Labrador Retriever & 29.8 & Male & 9 & No \\
G II & Pitbull & 31.7 & Female & Female & No \\
G II & Golden Retriever & 30 & Male & Adult & No \\
G I & Bull Terrier & 27.9 & Male & 10 & 6.9
\end{tabular}


Table 2. Mean and standard deviation of the lumbosacral intervertebral disc measurements obtained from anatomical specimens, radiographs, and computed tomography in the

transverse and sagittal section, from Groups I and II

\begin{tabular}{lcccc}
\hline \multirow{2}{*}{ Measurement site } & \multicolumn{3}{c}{ Mean and standard deviation (mm) } \\
\cline { 2 - 5 } Anatomical specimens & \multicolumn{3}{c}{ Sagittal } & \multicolumn{2}{c}{ Transverse } \\
& T2 & $6.312 \pm 1.11$ & H1 & $12.18(10.3-13)^{*}$ \\
& T3 & $6.853 \pm 1.135$ & H2 & $13.29 \pm 1.384$ \\
& DH & $13.992 \pm 1.704$ & H3 & $12.178 \pm 1.674$ \\
Radiography & T1 & $7.28 \pm 0.879$ & - & $24.73 \pm 6.251$ \\
& T2 & $7.28 \pm 0.719$ & - & - \\
Computed & T3 & $7.68 \pm 1.308$ & - & - \\
tomography & DH & $14.3 \pm 1.219$ & - & - \\
& T1 & $4.92 \pm 1.604$ & H1 & $11.8(5.4-15)^{*}$ \\
& T2 & $5.61 \pm 1.758$ & H2 & $12.64 \pm 1.662$ \\
& T3 & $5.69 \pm 1.832$ & H3 & $12.6 \pm 1.710$ \\
& DH & $14.4 \pm 1.557$ & W & $24.74 \pm 3.177$
\end{tabular}

* Median values (minimum value - maximum value obtained), nonparametric statistical test; $\mathrm{T} 1=$ thickness dorsal portion IVD, $\mathrm{T} 2=$ thickness central portion IVD, T3 = thickness ventral portion IVD, DH = IVD height, $\mathrm{W}=$ IVD width, $\mathrm{H}=$ heights at central point (H2) and laterally (H1 and $\mathrm{H} 3$ ).

Table 3. Mean and standard deviation of the lumbosacral intervertebral disc measurements obtained from radiographs and computed tomography in the transverse section or ventrodorsal view, from Groups I and II

\begin{tabular}{rccc}
\hline & & Mean and standard deviation $(\mathrm{mm})$ & p values \\
\hline Radiography & V1R & $2.36 \pm 1.177$ & \\
& V1L & $1.9(1.1-5.2)^{*}$ & \\
V2R & - & \\
V2L & - & \\
V3R & - & V1R 0.007 \\
V3L & $4.385 \pm 1.743$ & V1L 0.003 \\
Tomography & V1R & $3.83(2.31-7.11)^{*}$ & \\
V1L & $3.976 \pm 1.137$ & \\
V2R & $3.997 \pm 1.479$ & \\
V2L & $5.323 \pm 1.702$ & \\
V3R & $5.592 \pm 2.415$ &
\end{tabular}

* Median values (minimum value - maximum value obtained), nonparametric statistical test; $\mathrm{V}=$ disc thickness, $\mathrm{V} 1$ = dorsal portion, $\mathrm{V} 2$ = medial portion, $\mathrm{V} 3$ = ventral portion, $\mathrm{R}=$ right $\mathrm{L}=$ left.
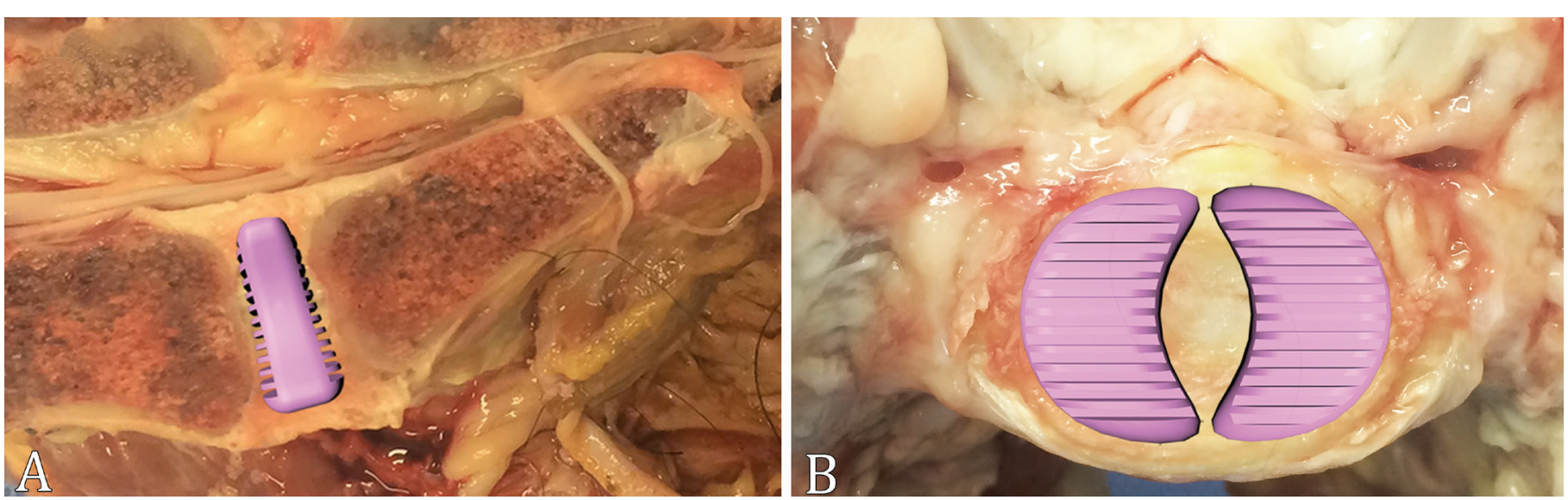

Fig.5. Positioning of the canine intervertebral cage model developed in the intervertebral disc space. (A) Sagittal view, (B) caudal view.
(V1) in dorsal view were significantly different $(\mathrm{p}<0.05)$ (Table 3). For each measure in both groups, it was compared the specimens with and without L7-S1 degenerative signs (Table 4), and no significant differences were found between the measurements ( $p>0.05)$.

Phase two. The Striker, Baumer Orthopedics, and LDR cages used in humans had higher, thicker and wider values than those of the anatomical specimens. The Synthes and Vertebral Technologies, Inc. models had thickness values near those of the specimens; however, the width and height values were higher. Thus, no specific lumbosacral cage model for human use fit the measurements obtained for the large dogs in this study. The cervical cages evaluated had measurements near those of the specimens, but their shapes made it impossible to implant them using the surgical dorsal laminectomy technique without injuring the cauda equina or the $\mathrm{L} 7$ nerve root.

Phase three. A model (Fig.4) was designed and shaped per the obtained measurements, considering the anatomical characteristics of the dogs' L7-S1 intervertebral space and presence of the cauda equina. It was followed the procedure recommended in human medicine for using two implants, one on each side of the intervertebral space (Fig.5).

\section{DISCUSSION}

Surgeries in the lumbosacral region in dogs are unsuccessful in up to $30 \%$ of cases, and the reasons may be the weak vertebral stability promoted by existing surgical techniques after dorsal laminectomy, lack of neuroforaminal decompression and an
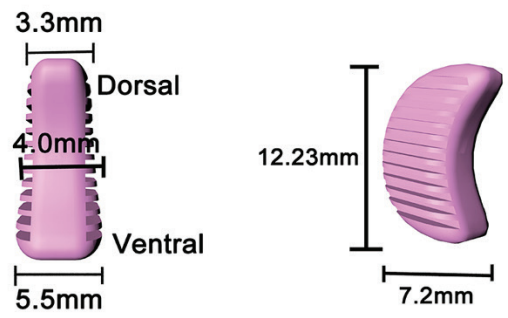

B

C

Fig.4. Intervertebral lumbosacral cage model developed for dogs. with dorsal, medial and ventral thickness, (B) caudal view with height and length, (C) dorsal view. Perspective and measurements of the cage. (A) Medial view 
absence of intervertebral bony fusion. In a cadaveric study it was obtained satisfactory biomechanical results and restauration of the intervertebral disc height after implanting a cervical intervertebral cage used in humans between the L7-S1 vertebrae in dogs, but the authors reported difficulty in inserting the cage in smaller dogs (Teunissen et al. 2017), evidencing the need to develop adequately sized lumbosacral cages for different sized dogs to promote vertebral distraction/fusion.

In this study, the canine lumbosacral spine of large breed dogs was evaluated because they are more affected by DLS. Changes compatible with lumbosacral degeneration were found in four dogs, which apparently caused no clinical signs of DLS. These changes may occur in animals with no clinical evidence of the disease and changes in imaging tests had little correlation with clinical findings of DLS (Rossi et al. 2004, Mattoon \& Koblik 2013). Thus, it was chosen to use the specimens from these dogs because the cage to be developed should also adapt to the disc space of dogs with lumbosacral degeneration. The degenerative changes did not alter the articulation between L7 and S1 to the point of interfering in obtaining the measurements.

The intervertebral space was measured directly on anatomical specimens, which were then analysed using radiography and CT. The anatomical specimens could not be used simultaneously for transverse and sagittal sections; thus, the same number of specimens could not be compared by the two imaging techniques. Because radiographic examination is the most common method for surgical planning in orthopaedics, its contribution to this study was evaluated. Obtaining transverse planes using radiography is impossible; thus, its use was limited to developing the cage model. The radiographic measurements were unreliable, probably due to the bone overlap in the ventrodorsal projection, while CT allowed several views and measurements. CT is a non-invasive method for visualizing tissues, without overlapping structures. It is considered superior to radiography for detecting DLS (Jones \& Inzana 2000, Axlund \& Hudson 2003, Higgins et al. 2011), and it allowed the specimens in several views to be accurately measured.

Cages specific for the human lumbar region are larger than that measured here, especially for the model developed to be implanted dorsolaterally. Human cages used for cervical stabilization had measurements similar to the model found in this study; however, due to their quadrangular shape, the possibility of being introduced surgically through L7-S1 dorsal laminectomy in dogs, without injuring the cauda equina or the $\mathrm{L} 7$ root is small. The smallest available cage for the human cervical spine was inserted into the canine lumbosacral spine in a cadaveric study, but the authors reported difficulties surgically implanting it in smaller dogs (Teunissen et al. 2017).

The intervertebral screw developed for dogs (FITS) provided adequate spacing between the L7 and S1 endplates and a satisfactory increase of the intervertebral foramen when inserted via dorsal laminectomy and central annulectomy (Farrel \& Fitzpatrick 2015, Fitzpatrick 2017, Zindl et al. 2018). However, the cauda equina had to be retracted to insert and fix the spacer with a screw, which is a risky intervention and caused temporary tail flaccidity in $11.1 \%$ of dogs, that resolved within six weeks (Fitzpatrick 2017). In the present study, the implant models were also developed to be inserted via dorsal laminectomy but placed laterally to the midline, and this reduces the likelihood of nerve root damage. The cage surface was developed to be serrated, to prevent using the locking screw to fix it, thus avoiding further injury to nerve structures. To develop our model, we also considered studies on humans, that showed that the lateral regions of the endplates support a more considerable load, and that the center of the bone, where implants are currently placed, is the weakest part of the lumbar end plate (Grant et al. 2001). Unfortunately, similar studies have not been performed in dogs.

Our cage was designed to allow graft placement in the surrounding intervertebral space, which is fundamental for fusion through integration between the cage and the endplates as well as for bone growth between and around the cage (Cho et al. 2008, Abbushi et al. 2009). The serrated surfaces are also designed to avoid cage migration and promote stability (Cho et al. 2008). Combining cage use with pedicled dorsal stabilization may increase the contact between the endplates and the serrated surface. In dogs, pedicle screw-rod fixation alone, without the use of a cage, does not result in interbody vertebral bone fusion between L7 and S1 (Tellegen et al. 2015). On the other side, when FITS is placed together with PSRF in dogs, the vertebrae are distracted first, the screw is then implanted, the distraction is decreased, and the device is compressed, increasing the chances of bone growth and intervertebral fusion. This was seen by means of computed tomography in 35 dogs submitted to PSRF, and it was observed that with the placement of the interbody spacer the neuroforamen was restored and it was provided a conduit for fibro-osseous fusion of the interbody space (Fitzpatrick 2017).

Some studies in humans have shown the importance of cage size and contact area to avoid cage migration (Krammer et al. 2001, Tan et al. 2005). Larger cages tend to have larger contact surface areas at the endplate/cage interface and thus lower stress concentration at a single point. We considered these factors in our study; thus, the developed models followed the increased intervertebral space in the dorsoventral direction, increasing their contact with the L7 and S1 bone surfaces. The threaded intervertebral bolt developed by Fitzbionics Ltd $^{\circledR}$ is $19 \mathrm{~mm}$ long, with a diameter of $7.5 \mathrm{~mm}$ proximally and $4.4 \mathrm{~mm}$ distally and was tested in cadaveric canine lumbosacral spines of dogs weighing between $25.0-39.5 \mathrm{~kg}$, but the bolt format and thickness is greater in the dorsal part of the disc, and smaller in the ventral part (Zindl et al. 2018), which is inverse to the measurements obtained in our study. Further studies should be performed to verify if the screw configurations in relation to the disk measurements can affect the biomechanics of the intervertebral space after surgical stabilization with this kind of implant system.

The prosthesis design was also based on conceptions in human medicine. We considered the adequacy to the anatomy and dimensions of the canine lumbosacral region, the load that the cages must bear, the material for implant manufacturing, its positioning within the intervertebral space, and the apparatus biomechanics to prevent cage migration (Spruit et al. 2005, Cutler et al. 2006). However, it was observed in human experimental studies that cage geometry, including the shape (curved or straight), length, and surface (biconvex or flat), did not affect the implants' stability when used in combination with posterior fixation (Cho et al. 2008). 


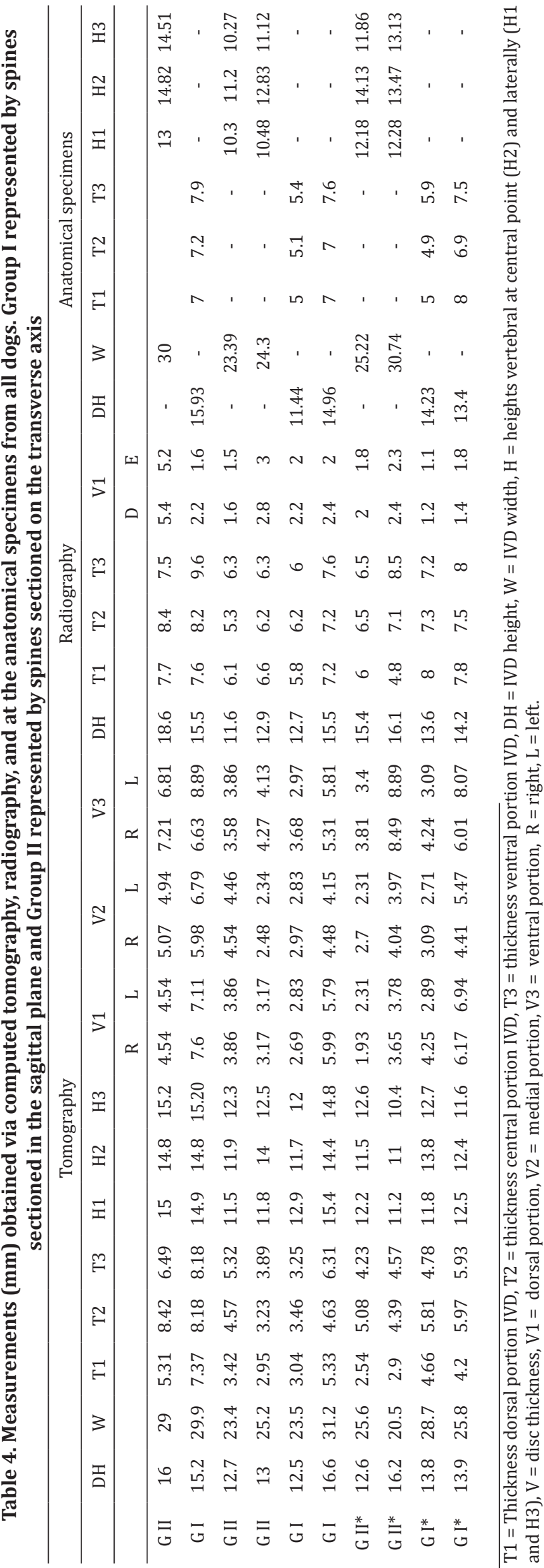

The 3DS MAX 2015 software allowed designing two cage models according to the contour of the bone surfaces and the intervertebral space size. In the future, these cage models can be adapted and reshaped to better fit the L7-S1 segment, since 3D technology is widely used in human medicine and is promising in veterinary medicine for facilitating surgical planning and improving research (Hespel et al. 2014, Joffe et al. 2019). To measure disc space, radiography should be used with caution, as CT better delineates the contact areas between the endplate and the cage, with more reliable measurements.

\section{CONCLUSIONS}

Computed tomography (CT) was superior to radiography for determining the intervertebral space measurements used to develop the implants.

Human lumbosacral cages did not fit the average measurements of the L7-S1 space; thus, no models were found for the lumbosacral region that could be used in dogs.

We developed a cage prototype for dogs via 3D modelling that could be applied dorsolaterally to the L7 intervertebral space to promote lumbosacral intervertebral fusion/distraction, considering the intervertebral anatomy of the species and the CT measurements of the disc space. The degenerative changes observed in four spines did not alter the articulation between L7 and S1 to the point of interfering in obtaining the measurements.

Ex vivo and in vivo studies with the developed cage models are necessary to evaluate the actual degree of distraction, mobility and the long-term rate of fusion between L7 and S1 and its possible impact on the adjacent motor units, combined or not with dorsal fixation techniques.

Acknowledgements.- The authors are grateful to the "Coordenação de Aperfeiçoamento de Pessoal de Nível Superior" (CAPES) for the scholarship provided to R.C. Dias and the Small Animal Neurology Teaching Project/UEL for funding part of the study.

Conflict of interest statement.- The authors have no competing interests.

\section{REFERENCES}

Abbushi A., Cabraja M., Thomale U.W., Woiciechowsky C. \& Kroppenstedt S.N. 2009. The influence of cage positioning and cage type on cage migration and fusion rates in patients with monosegmental posterior lumbar interbody fusion and posterior fixation. Eur. Spine J. 18(11):1621-1628. <http://dx.doi.org/10.1007/s00586-009-1036-3> <PMid:19475436>

Axlund T.W. \& Hudson J.A. 2003. Computed tomography of the normal lumbosacral intervertebral disc in 22 dogs. Vet. Radiol. Ultrasound 44(6):630-634. <http://dx.doi.org/10.1111/j.1740-8261.2003.tb00521.x> <PMid:14703241>

Bebchuck T. 2017. Lumbosacral Decompression and foraminotomy, p.223233. In: Shores A. \& Brisson B.A. (Ed.), Current Techniques in Canine and Feline Neurosurgery. Wiley-Blackwell, New Jersey.

Cho W., Wu C., Mehbod A.A. \& Transfeldt E.E. 2008. Comparison of cage designs for transforaminal lumbar interbody fusion: a biomechanical study. Clin. Biomech. 23(8):979-985. <http://dx.doi.org/10.1016/j. clinbiomech.2008.02.008> <PMid:18675496>

Cutler A.R., Siddiqui S., Mohan A.L., Hillard V.H., Cerabona F. \& Das K. 2006. Comparison of polyetheretherketone cages with femoral cortical bone allograft as a single-piece interbody spacer in transforaminal lumbar interbody fusion. J. Neurosurg. Spine 5(6):534-539. <http://dx.doi. org/10.3171/spi.2006.5.6.534><PMid:17176018> 
Farrel M. \& Fitzpatrick N. 2015. Lumbosacral disc disease: is vertebral stabilization indicated?, p.237-250. In: Fingeroth J.M. \& Thomas W.B. (Ed.), Advances in Intervertebral Disc Disease in Dogs and Cats. WileyBlackwell, Iowa.

Fitzpatrick N. 2017. Lumbosacral disease: diagnosis and treatment. World Small Animal Veterinary Association Congress Proceedings, Copenhaguem, Denmark, p.1-4.

Gomes S.A., Lowrie M. \& Targett M. 2018. Long-term outcome following lateral foraminotomy as treatment for canine degenerative lumbosacral stenosis. Vet. Rec. 183(11):352. <http://dx.doi.org/10.1136/vr.104741>

Grant J.P., Oxland T.R. \& Dvorak M.F. 2001. Mapping the structural properties of the lumbosacral vertebral endplates. Spine 26(8):889-896. <http://dx.doi.org/10.1097/00007632-200104150-00012><PMid:11317111>

Hespel A.M., Wilhite R. \& Hudson J. 2014. Invited review - applications for 3D printers in veterinary medicine. Vet. Radiol. Ultrasound 55(4):347-358. <http://dx.doi.org/10.1111/vru.12176> <PMid:24889058>

Higgins B.M., Cripps P.J., Baker M., Moore L., Penrose F.E. \& McConnell J.F. 2011. Effects of body position, imaging plane, and observer on computed tomographic measurements of the lumbosacral intervertebral foraminal area in dogs. Am. J. Vet. Res. 72(7):905-917.<http://dx.doi.org/10.2460/ ajvr.72.7.905 > <Mid:21728851>

Jeffery N.D., Barker A. \& Harcourt-Brown T. 2014. What progress has been made in the understanding and treatment of degenerative lumbosacral stenosis in dogs during the past 30 years? Vet. J. 201(1):9-14. <http://dx.doi.org/10.1016/j.tvjl.2014.04.018> <PMid:24878265>

Jeffery N.D., Levine J.M., Olby N.J. \& Stein V.M. 2013. Intervertebral disk degeneration in dogs: consequences, diagnosis, treatment, and future directions. J. Vet. Intern. Med.27(6):1318-1333.<http://dx.doi.org/10.1111/ jvim.12183><PMid:24010573>

Joffe M.R., Parr W.C.H., Tan C., Walsh W.R. \& Brunel L. 2019. Development of a customized interbody fusion device for treatment of canine disc-associated cervical spondylomyelopathy. Vet. Comp. Orthop. Traumatol. 32(1):79-86. <http://dx.doi.org/10.1055/s-0038-1676075> <PMid:30646415>

Jones J.C. \& Inzana K.D. 2000. Subclinical CT abnormalities in the lumbosacral spine of older large-breed dogs. Vet. Radiol. Ultrasound 41(1):19-26. <http://dx.doi.org/10.1111/j.1740-8261.2000.tb00421.x><PMid:10695875>

Kim H., Lee C.K, Yeom J.S, Lee J.H., Lee K.H. \& Chang B.S. 2012. The efficacy of porous hydroxyapatite bone chip as an extender of local bone graft in posterior lumbar interbody fusion. Eur. Spine J. 21(7):1324-1330. <http://dx.doi.org/10.1007/s00586-011-2092-z> <PMid:22139050>

Krammer M., Dietl R., Lumenta C.B., Kettler A., Wilke H.J., Büttner A. \& Claes L. 2001. Resistance of the lumbar spine against axial compression forces after implantation of three different posterior lumbar interbody cages. Acta Neurochir. 143(12):1217-1222. <http://dx.doi.org/10.1007/ s007010100017>

Mattoon J.S. \& Koblik P.D. 2013. Quantitative survey radiographic evaluation of the lumbosacral spine of normal dogs and dogs with degenerative lumbosacral stenosis. Vet. Radiol. Ultrasound 34(3):194-206. <http://dx.doi.org/10.1111/j.1740-8261.1993.tb02005.x>

Meij B.P. \& Bergknut N. 2010. Degenerative lumbosacral stenosis in dogs. Vet. Clin. N. Am., Small Anim. Pract. 40(5):983-1009. <http://dx.doi.org/10.1016/j.cvsm.2010.05.006> <PMid:20732601>

Polly D.W., Klemme W.R., Cunningham B.W., Burnette J.B., Haggerty C.J \& Oda I. 2000. The biomechanical significance of anterior column support in a simulated single-level spinal fusion. J. Spinal Disord. 13(1):58-62. <http://dx.doi.org/10.1097/00002517-200002000-00012><PMid:10710152>

Rossi F., Seiler G., Busato A., Wacker C. \& Lang J. 2004. Magnetic resonance imaging of articular process joint geometry and intervertebral disk degeneration in the caudal lumbar spine (L5-S1) of dogs with clinical signs of cauda equina compression. Vet. Radiol. Ultrasound 45(5):381-387. <http://dx.doi.org/10.1111/j.1740-8261.2004.04083.x><PMid:15487561>

Solano M.A., Fitzpatrick N. \& Bertran J. 2015. Cervical distraction-stabilization using an intervertebral spacer screw and string-of pearl ( $\mathrm{SOP}^{\mathrm{TM}}$ ) plates in 16 dogs with disc-associated Wobbler syndrome. Vet. Surg. 44(5):627-641. <http://dx.doi.org/10.1111/vsu.12325><PMid:25929590>

Spruit M., Falk R.G., Beckmann L., Steffen T. \& Castelein R.M. 2005. The in vitro stabilizing effect of polyetheretherketone cages versus a titanium cage of similar design for anterior lumbar interbody fusion. Eur. Spine J. 14(8):752-758. <<http://dx.doi.org/10.1007/s00586-005-0961-z> $<$ PMid:16133078>

Tan J.S., Bailey C.S., Dvorak M.F., Fisher C.G. \& Oxland T.R. 2005. Interbody device shape and size are important to strengthen the vertebra-implant interface. Spine 30(6):638-644. <http://dx.doi.org/10.1097/01. brs.0000155419.24198.35><PMid:15770178>

Tellegen A.R., Willems N., Tryfonidou M.A. \& Meij B.P. 2015. Pedicle screw-rod fixation: a feasible treatment for dogs with severe degenerative lumbosacral stenosis. BMC Vet. Res. 11:299. <http://dx.doi.org/10.1186/s12917-0150614-3> <PMid:26642756>

Teunissen M., Van Der Veen A.J., Smit T.H., Tryfonidou M.A. \& Meij B.P. 2017. Effect of a titanium cage as a stand-alone device on biomechanical stability in the lumbosacral spine of canine cadavers. Vet. J. 220:17-23. <http://dx.doi.org/10.1016/j.tvjl.2016.12.007> <PMid:28190488>

Zindl C., Litsky A.S., Fitzpatrick N. \& Allen M.J. 2018. Kinematic behavior of a novel pedicle screw-rod fixation system for the canine lumbosacral joint. Vet. Surg. 47(1):114-124. <http://dx.doi.org/10.1111/vsu.12742> $<$ PMid:29105787> 